\title{
Transported into the Bosom of the Empire?-Rethinking How Arthur Conan Doyle Persuades His Readers of British Imperialism in "The Speckled Band"*
}

\author{
Billy Bin Feng Huang (黃斌峰) \\ National Chengchi University, Taipei, Taiwan (R.O.C)
}

\begin{abstract}
Melanie C. Green and Timothy C. Brock have proposed their transportation-imagery model of narrative persuasion. They argue that a narrative can evoke imagery in readers' mind and then transport readers into the narrative world the author has created, in the course of which the author can persuade readers of the beliefs he's put into the narrative. This paper employs this model to rethink how Arthur Conan Doyle persuades his readers of British imperialism in his "The Speckled Band". First, this model considers the vividness of the narrative and readers' participatory response as key factors in readers' transportation. The narratives of "The Speckled Band" are picturesque, and Sherlock Holmes' inferential process has reinforced readers' participatory response. On the other hand, detective fiction usually has the theme of how the detective/law and order beats the criminal/chaos. That is, Doyle persuades his readers that the British Empire will prevail in "The Speckled Band" when Holmes, representing the British imperialism, solves the case and kills Dr. Roylott, who represents the evil and savagery in the British colony. According to Green and Brock's model, it simply means that there are two narratives (i.e., one is about how the law of the British Empire is challenged, and the other is about how the British Empire's stability is restored), and two complementary transportations before Doyle can successfully persuades his readers. However, if we closely read "The Speckled Band", we can learn that Holmes, who should have represented British law, is guilty of trespassing or taking the law into his own hands. In other words, the complementarity of the two transportations is compromised. Thus, we can conclude that it is highly questionable whether or not Doyle can transport his readers into the bosom of the British Empire.
\end{abstract}

Keywords: Arthur Conan Doyle, "The Speckled Band", transport(ation), narrative, persuade(-sion), British imperialism

\section{Introduction}

Emotion is to fiction as truth is to science...Fictional narrative has its impact primarily through the emotions. When an emotion occurs, we experience it as striking. Sometimes a novel can affect a person's whole identity.

- Keith Oatley,

Emotions and the Story Worlds of Fiction (2002)

\footnotetext{
* This paper was also presented in the International Conference of AVSA in the University of Hong Kong on July 11, 2014. Here the author would like to express his deepest appreciation for the anonymous reviewer's opinions on this paper.

Billy Bin Feng Huang, Ph.D. candidate, English Department, National Chengchi University.
} 
Finally there's the solution of the puzzle and this may be why the detective story is so popular in ages of anxiety...That may well be the attraction of these small literary celebrations of order and reason in our increasingly disordered world.

-P. D. James,

The Art of the Detective Novel (1989)

Labov (1972) defines a narrative as "one method of recapitulating past experience by matching a verbal sequence of clauses to the sequence of events which (it is inferred) actually occurred" (pp. 359-60). That is, a narrative is a way of verbally reorganizing certain past events, actual or non-actual. And Oatley has argued that even a fictional narrative has a striking power of evoking readers' emotions or even changing their identities. On the other hand, a detective story is basically a process of how a mystery is unfolded and eventually solved. According to James, a detective story fundamentally reflects readers' anxiety about the world's disorder as well as their longing for reason and order. Of course, James here refers to classical detective stories ${ }^{1}$, like Edgar Alan Poe's or Arthur Conan Doyle's. Though the detectives these writers have created may range from a "thinking machine" who always sits still to reason out the truth, such as Dupin, to an "action hero, [who is] always at the scene of the crime" (Groves, 2003, p. 471, italics mine), such as Holmes, it is basically accurate to say that they incarnate reason and justice of their societies. That is to say, as readers get transported into a detective story, they will supposedly reinforce their belief in the importance of law and order in society. The aim of this paper is to employ Melanie C Green and Timothy C. Brock's transportation-imagery model of narrative persuasion to rethink Doyle's strategy of transporting his readers into the bosom of the British Empire in "The Speckled Band", a story about how a colonial criminal, "who simply don't belong in English society, trespass(es) against English values and institutions" (McBratney, 2005, p. 157). To be more specific, by drawing on Green and Brock's model the author intend to re-examine how Doyle, through the agency of his characterization of Sherlock Holmes, persuades his audience of British imperialism, or to take notice of how the British Empire maintains its stability in "The Speckled Band".

\section{The Transportation-Imagery Model of Narrative Persuasion}

In their essay In the Mind's Eye, Green and Brook have constructed their transportation-imagery model of narrative persuasion. According to them, this model consists of five basic postulates: (1) narrative persuasion is limited to story texts, where readers' images are evoked and readers' beliefs are implicated; (2) evoked images enable readers to become absorbed in the narrative world to the extent of leaving behind the real world, at least temporarily; (3) propensity for transportation is affected by readers' attributes (e.g., imagery skills); (4) propensity for transportation is affected by attributes of the text (e.g., artistic craftsmanship); (5) propensity for transportation is affected by the attributes of the context (e.g., aspects of the context that limit opportunity for imaginative investment and participatory responses) (pp. 316-7).

Evidently, Green and Brook's model is built upon a formula: Readers tend to create imagery in their minds as they read a narrative; simultaneously, they get transported into the narrative world, in the course of which the narrative will exert their persuasive power over readers. This formula has three variables: the factors of the reader, the factor of the text, and the factor of the context. First of all, Green and Brook's model highlights the

\footnotetext{
${ }^{1}$ As we all know, detective fiction has come a long way in both America and England. From the classical detective fiction have developed the hard-boiled or metaphysical detective stories, both of which differ considerably from traditional ones in essence. My paper deals with "The Speckled Band", a paradigm of classical detective fiction. Therefore, when I speak of detective stories or fiction in this paper, I refer to the classical type unless I state otherwise.
} 
significance of readers' creation of mental imagery, "a representation of a particular stimulus that is formed by activation of a sensory system and, thus, is experienced by the organism as having similar qualities to the actual perception of the stimulus" (Dadds, Bovgjerg, Reed, \& Cutmore, 1997, p. 90). They believe that it is the cataclysm for narrative transportation as well as narrative persuasion. After his thorough research on reading activities in Lost in a Book: The Psychology of Reading for Pleasure, Nell (1988) concludes that "the reader, using a ready-made store of images, at once sees the whole picture - mistily, perhaps, but well enough...vivid imagery is indeed frequently associated with reading involvement" (p. 246). Drawing on Nell's conclusion, Green and Brook validate their theory of linking "the subjective experience of transportation with the formation of mental images" (p. 322). It is these images that cause readers to lose "access to some real word facts in favor of accepting the narrative world the author has created". For instance, "a person transported by a story may not notice others entering or leaving the room" (p. 325). Above all, once the correspondence between readers' mental images and their transportation is confirmed, we can get to perceive how readers get persuaded by the narrative. Here, Green and Brook make it clear that "whether the text is labeled as fact or fiction (as true or not necessarily true), does not limit transportation" (p. 317); namely, the actuality of the text, namely, whether or not the text is true, is irrelevant to its ability to transport readers. As a matter of fact, a great deal of research dealing with narrative persuasion has echoed their viewpoint, proving it to have a solid rationale. First, Bruner (1986) differentiates a good story from a well-informed argument, stating that the latter "establishes not truth but verisimilitude" (p. 11). Strange and Leung (1999) assert that stories' verisimilitude has the function of getting indexed into memories. That is, stories can evoke "memories of similar characters and causal circumstances in the minds of the readers" (p. 444). Schank and Abelson (1995) also agree with them, saying that "stories...are the fundamental constituents of human memory, knowledge, and social communication...when it comes to interaction in language, all of our knowledge is contained in stories and mechanisms to construct them and retrieve them" (pp. 1-2). Strange (2002) further points out that fiction, once working its way into readers' memory, can "vastly extend the life space that constitutes our everyday worlds. Through the vehicle of fiction, we are invited to reconceptualize present, past, and future, and to consider alternatives to our entrenched points of view" (p. 282). To put it simply, readers do get persuaded by fictional narratives, though they are indeed conscious of their untruthfulness ${ }^{2}$.

To sum up, Green and Brook's formula of narrative persuasion has factored in three variables, as is previously mentioned. First, Green and Brook argue that readers' "ability to create vivid images and to experience absorption are two conceptually distinct capabilities that may function multiplicatively to facilitate transportation" (p. 327). That is, it is generally agreed that the more imaginative and inclined to get absorbed a reader is, the easily (s)he will get transported into a narrative world. Secondly, they believe it is no doubt that "the artistic craftsmanship of the book or film has some responsibility for enormous differences in reader [viewer] appreciation" and "should directly affect amount of transportation and, hence, persuasive impact" (p. 328). To buttress their argument, they have selected "Murder at the Mall", a "highly involving, imagery-rich",

\footnotetext{
${ }^{2}$ Quite a bit research has been conducted with regard to the persuasiveness of fiction. For instance, both Searle and Pratt have seen how humans are susceptible to fiction. The former observes, "It is after all an odd, peculiar, and amazing fact about human language that it allows the possibility of fiction at all. Yet we all have no difficulty in recognizing and understanding works of fiction". The latter gives a personal experience, "Without the slightest hint of infidelity, I can recount an anecdote I heard from someone else whose name I can't remember to an audience I don't know about events I didn't witness that happened somewhere I've never been". Both of them believe that our susceptibility to fiction can increase its power to persuade readers. See Searl (1975) and Pratt (1977).
} 
and extraordinarily realistic narrative. It is "a story about a college student, Joan, whose little sister Katie is brutally stabbed to death by a psychiatric patient while they are at the mall". Green and Brook have done their own research, and drawn on other scholars' as well. Then, they conclude that the vivid imagery in the story is responsible for readers' acceptance of the belief that "individuals with violent mental disorders should not be allowed in the community without supervision (if at all!)" (pp. 318-9). In other words, the better a text is written, the more transportation it can induce, and the more persuasive it can be. Last but not least, Green and Brook emphasize the factor of readers' participatory responses (p-responses), which are activities such as "thoughts about characters, expressions of preferences about events, or reflections on the broader implications of the story" (Allbritton \& Gerrig, 1991, p. 604). Polichak and Gerrig (2002) suggest that "readers can be conceptualized as side-participants with respect to their experiences of narratives" (p. 73). By "side-participants", they refer to the readerly roles such as indirect addressees, or even overhearers in a conversation. They conclude that readers, adopting this role, have made the p-responses that help define their emotional experience and shape their "long-term mental representations of a narrative" (p. 92). Gerrig (1993), in his Experiencing Narrative Worlds, has further pointed out:

In particular, I suggested that authors treat readers as side-participants toward whom they direct sincere informatives. What often matters to readers' experiences of narratives is...how they [authors] parcel out information within the text. Much of my focus has been on the cognitive processes readers undertake to construct appropriate representations of this knowledge. (p. 156, italic mine)

Gerrig has argued that the reader, by assuming the role as a side-participant, can produce the p-response ${ }^{3}$ that can facilitate his or her cognitive processes of digesting the information the author has embedded in the narrative. With such a facilitation, "people are able to develop an understanding of the past, an expectation about the future, and a general understanding of how they should act" (Jacobs, 2002, p. 206). To put it simply, they get persuaded and thus changed ${ }^{4}$.

\section{The Narrative Persuasion of "The Speckled Band"}

The above is an overview of Green and Brock's transportation-imagery model of narrative persuasion, whose studies today have been correlated to different areas ${ }^{5}$. My next step is to conflate this model with Doyle's "The Speckled Band". As we have mentioned above, this model centralizes the role of the text's imagery. In his Pragmatics and Fiction, Adams (1985) suggests that:

since we cannot meet fictional character — which I think can be taken to be self-evident - we cannot go to any place that would make such a meeting possible. So in the case of the Sherlock Holmes stories, there must be two Londons, each with its own Baker Street, one in our world and one in Sherlock Holmes's world. And since we cannot enter a fictional world and since fictional characters cannot enter our world, fictional characters remain unaware of the real world and are, therefore, unable to talk about it. (pp. 21-2)

\footnotetext{
${ }^{3}$ Gerrig and Prentice (1996) argue that films are more likely to elicit p-responses. They state that "formal properties of film—and particularly, the ability of film to fix the focus of attention-make it especially likely that such as if responses will occur...even more than in the experience of text-individuals are likely to lose track of the fact that they can't really participate".

${ }^{4}$ Shank and Berman (2002) have viewed readers' digestion of stories in the light of how memory restructures itself. They suggest that "we listen to stories with an innate ability to pull apart the details and fill out our memory structures where they are lacking. In essence, our knowledge is constructed of stories in various forms".

5 For instance, Slater (2002) has researched the narrative persuasion of entertainment education. He concludes, "The incidental and cumulative effect of entertainment narratives on beliefs, values and behaviors is one of the most important issues facing communication scientists. Critical and cultural scholars have long emphasized the importance of such effects in understanding the impact of media on contemporary society".
} 
It would appear that Adams has observed that the distinction between the real world and the fictional world remains hard and fast. However, in commenting on the quoted passage, Gerrig first admits that Adams emphasizes the impossibility that "real people could have met Sherlock Holmes on the streets of London". Then he points out that Adams has also hinted at the possibility that "readers treat Sherlock Holmes's London as the real London" (Gerrig, 1993, p. 206). On the one hand, Gerrig's observation is congruent with Green and Brock's postulate: the fact that a narrative is fiction does not diminish its power to persuade. Readers are aware that the accounts in Sherlock Holmes stories "are far closer to fiction than many Victorians with confidence in reason and scientific progress might acknowledge" (Frank, 2003, p. 158). Even so, they can't help being drawn into the narrative world Doyle has created, "treating it as the real London". On the other hand, Gerrig's observation may be seen in terms of the author's craftsmanship, which means that Doyle has managed to present vivid visual imagery to his readers in his Sherlock Holmes stories, such as the scene of Julia's murder in The Speckled Band:

She [Julia] writhed as one who is in terrible pain, and her limbs were dreadfully convulsed. At first, I [Helen] thought that she had not recognized me, but as I bent over her she suddenly shrieked out in a voice which I shall never forget, "O, my God! Helen! It was the band! The speckled band!”...and she stabbed with her finger into the air in the direction of the Doctor's room, but a fresh convulsion seized her and choked her words. (Doyle, 1996a, p. 218, italics mine)

Doubtless, this scene of "The Speckled Band", does remind us of Green and Brock's "Murder at the Mall" in both the stories a young girl dies a tragic death. As the former persuades the readers of certain attitudes and beliefs, so does Doyle's "The Speckled Band" can. But, let's focus on the vivid imagery of "The Speckled Band" first. It is noteworthy that Doyle's ability to ornament his stories with graphic details has also evoked his readers' imagination.

The combination of science and panache [in Sherlock Holmes stories] was irresistible to the reading public...he [Doyle] had found a place in both the mind and heart of the popular imagination, unrivalled by almost any other fictional creation, certainly any fictional detective. (Wolfreys, 1996, p. x, italics mine)

Creating the character of Sherlock Holmes, who is "half doctor, half virtuoso" (Wolfreys, 1996, p. x), Doyle has captured the reading public's imagination better than almost any writer of detective stories. For instance, in The Speckled Band, Sherlock Holmes gathers from "a small saucer of milk which stood on the top of" (p. 223) the safe that Dr. Grimesby Roylott, Helen and Julia's evil stepfather, must be keeping a snake. And in the end of the story, Sherlock Holmes attacks the snake with a cane. "Some of the blows of my cane came home, and roused its snakish temper, so that it flew upon the first person it saw" (p. 229). That is, Sherlock Holmes draws on his biological knowledge to solve the mystery and crack the case. In spite of the pseudo-science here, that is, the fact that the cold-blooded reptile like the snake can't possibly feed on milk, Sherlock Holmes's impressive detective skills can still enable readers' imagination to soar higher than usual.

In addition to evoking readers' imagination, Sherlock Holmes's inferential process is a mechanism designed to elicit readers' participatory responses. Batty (1987) comments on how author has created the effect of suspense, "...one of the criteria for judging the effective creation of suspense is the duration between promise and fulfillment: the longer disclosure is deferred, the greater the suspense" (p. 62). If we frame detective fiction with Batty's analysis of suspense, we can conclude that in reading a detective story, readers' suspense always remains; that is, when they begin reading it, they are aware that the solution to the mystery is 
promised. Then they see the detective gather clues and make fantastic inferences based on them. Not until they read about the solution in the end will their suspense fade away. For Gerrig, readers' suspense is precisely the origin of their p-response or transportation because their suspense is meant "to make readers wait as long as possible without exiting the narrative world in disgust or dismay" (p. 86). Here, my point is that in the case detective stories, readers' suspense constantly takes the form of their curiosity ${ }^{6}$. In her Detective Stories and the Primal Scene, before drawing the conclusion that "the reader addicted to mystery stories tries actively to relive and master traumatic infantile experiences he once had to endure passively" (p. 20), Pederson-Krag also admits that detective stories are characterized by their readers' tendency to identify with the characters, which surely brings them unlimited gratification. Above all, another "unique feature of the mystery story" is "the intense curiosity it arouses" (p. 15). Pederson-Krag has pointed out a crucial fact about the mystery story: the author of the mystery story continually plays on readers' curiosity to know how a mystery can be solved, in the course of which readers get transported into its narrative world, identifying themselves with the characters. It is precisely readers' curiosity that qualifies them to be side-participants. Black (1999) states that in classical detective stories, like Edgar Alan Poe's "The Purloined Letter", "the sleuth's attention and the reader's interest are directed to a document that plays a crucial role in the narrative" (p. 79). Robertson (2012) also notices that in a good detective narrative, "the reader is periodically led to believe that one protagonist, or another, may be the chief suspect in a crime..." (p. 472). That is, when the detective is focused on the clues, attempting to think out the answer to the mystery, readers, driven by their curiosity, can't help following the lines of the detective's thoughts ${ }^{7}$. Here we can see a usual case scenario of the detective story: it would be as if the author masterminded a mind game involving certain characters such as the detective, the victim(s), and the criminal(s); at the same time, the author also dared the readers to play this mind game if they could. Thus, the author has made his or her readers side-participants of the narrative. In "The Speckled Band", when the coroner "investigated the case with great care...but he was unable to find any satisfactory cause of death" (p. 218), readers' curiosity should be aroused. And their curiosity certainly gets even more heightened when they learn that Julia's death occurs in a completely "closed space":

My (Helen's) evidence showed that the door had been fastened upon the inner side, and the window were blocked by old-fashioned shutters with broad iron bars, which were secured every night. The walls were carefully sounded, and were shown to be quite solid all round, and the flooring was also thoroughly examined, with the same result. The chimney is wide, but is barred up by four large staples. It is certain, therefore, that my sister was quite alone when she met her end. (pp. 218-9, italics mine)

In the tradition of detective fiction, a "closed space" case is generally considered an ultimate challenge the author offers to his or her readers. Above all, it is sure to arouse readers' curiosity, for they are certainly dying to know the answer to this seemly impossible crime. After pointing out that the murder of Julia takes place in a

\footnotetext{
${ }^{6}$ In his The Typology of Detective Fiction, Todorov (1977) clearly distinguishes curiosity from suspense. For him, the former "proceeds from effect to cause: starting from a certain effect... we must find its cause". As for the latter, "we are first shown the cause, ... and our interest is sustained by...certain effects". However, it seems to me that Todorov's distinction may be applicable only in certain contexts. In this paper, I intend to refer to the original definition of suspense in Collins Cobuild English Dictionary, "a state of excitement or anxiety about something that is going to happen very soon". That is, I refer to how detective fiction excite its readers to learn how the case is solved. See "Suspense". Def. 1. Collins Cobuild English Dictionary (2nd ed.) and Todorov (1977).

7 Slavoj Zizek has provided a psychoanalytical explanation for this curiosity on readers' part. He believes readers are curious to read through detective fiction primarily because of their "shared feeling of guilt". That is, "the detective plays upon the difference between the factual truth (the accuracy of facts) and the 'inner' libidinal truth and discharges us of all guilt for the realization of our desire, insofar as this realization is imputed to the culprit alone" (Zizek, 1991, p. 59).
} 
closed space, Doyle continues to keep his readers in suspense as they see Sherlock Homes examine Dr. Roylott's chamber:

A camp bed, a small wooden shelf full of books, mostly of a technical character, an arm-chair beside the bed, a plain wooden chair against the wall, a round table, and a large iron safe were the principal things which met the eye. Holmes walked slowly round and examined each and all of them with the keenest interest. (p. 223)

Afterwards, Holmes "squatted down in front of the wooden chair, and examined the seat of it with the greatest attention" (pp. 223-4). Eventually, Sherlock Holmes reveals the answer: the "speckled band" is actually a "swamp adder", "the deadliest snake in India" (p. 228) (In fact, it is at this point where readers realize what Doyle wishes to persuade his readers of in the scene of Julia's death: a young English girl is killed by an alien snake, which is apparently symbolic of the compromised security of the British Empire). In addition, when he sees Dr. Roylott's chair, he determines that "he had been in the habit of standing on it". "The sight of the safe, the saucer of milk, and the loop of whipcord" all tell him that there is a "terrible occupant" (p. 229). Up until now have readers remained side-participants of the narrative.

According to Gerrig, authors treat readers as side-participants in order to direct sincere informatives to them. Here comes the central question: with his picturesque imagery, Doyle pulls his readers into the narrative world of "The Speckled Band", making them side-participants. What exactly does he want to persuade his readers of in this story? As "narratives...derive much of their power from...the fact that there is some consensus in what people are likely to take from them" (Johnson \& Foreword, 2002, p. xi), there must be a set of attitudes and beliefs Doyle has encoded in the language of the story, or we might as well throw the story away (Gibson, 1980, p. 1). To answer this question, we have to understand certain underlying principles of the detective story. Cohen (2000) in his Murder Most Fair, argues that in detective fiction, "society is by nature law-abiding, most people are truth-tellers, and crime is an aberration" (p. 27). "It is the task of the detective to discover what has happened, to sort out the evidence, arrive at a conclusion and pass on the knowledge to judicial process" (Erb, 2007, p. 115). Those living in urban areas are mostly convinced that their cities don't deserve to be contaminated with chaos and evil; therefore, the story about how the detective brings the transgressor to justice can certainly appeal to them because it reinforces their belief in the good values their cities should possess ${ }^{8}$. This is also why Dana Brand states that "the detective resolves a mystery that is emblematic of urban experience itself" (Brand, 1990, p. 237). Equipped With pure reasoning and inferential skills, the private detective becomes the last line of defense of social order, just as Tony Bennett has observed, "the private eye" of the detective becomes a great helper for "the public eye of power" (Bennett, 1986, p. 216). In other words, human reason and society's law and order are both indexed and clustered together within the parameters of classical detective fiction. Sherlock Holmes, with his encyclopedic understanding of London and the keys to every Londoner's living room in his hands (Rothfield, 1992, p. 139), certainly assumes the part as the defender of the order and stability of London, the imperial center. In "The Speckled Band", Sherlock Holmes beats Dr. Roylott, a man with "violence of temper approaching mania...intensified by his long residence in tropics" (p. 216), and rescues Helen from the adder originating from an alien culture. Susan Cannon Harris points out that "not only the manner of the crime but also the inclination to commit it should be

\footnotetext{
${ }^{8}$ Cawelti (1976) accuses popular literature of offering readers an escape from reality. For him, this is why popular literature can't be taken seriously. Detective fiction certainly falls into the category of popular literature. If so, detective fiction also enables its readers to escape from the hideous, disorderly realities of their cities, which echoes the quoted statement of P. D. James in the beginning of the paper.
} 
attributed to the criminal's contact with an alien culture" (Harris, 2003, p. 452, italics mine). Jon Thompson states that in Sherlock Holmes stories, Doyle combines "ideologically charged conventions from adventure, detective, and sensational literature" with "strategies of exclusion", which refer to how Sherlock Holmes contains and controls colonial contaminations (Thompson, 1993, p. 73). Furthermore, Lauren Raheja explicates the message Doyle wishes to convey in the story: such an Englishman as Roylott, after venturing into the "backward and immortal" colony of the British Empire, "would inevitably endanger the imperial center". As Sherlock Holmes manages to prevent the death of young Helen, he has restored "order after a brief period of savagery and disorder" (Raheja, 2006, p. 419). When the menace from Dr. Roylott is resolved at the end of the story, readers are reassured that London still maintains its law and order. In brief, Doyle composes "The Speckled Band" to persuade his readers of how unshakable the stability of the British Empire should be under any circumstances; the story, decorated with plenty of vivid imagery, enables him to transport his readers into the bosom of the British Empire. It is actually no surprise why Doyle wishes to persuade his readers of British imperialism. Diane Simmons argues that a lot of Victorian writers had such a "narcissistic fantasy" which "helped shape the understanding of the imperial role, so that finally empire was seen... as the glamorous, heroic and self-defining mission of a superior people" (Simmons, 2007, p. 2). Moreover, Anne McClintock writes, "By the end of the century, a stream of imperial bric-a-brac had invaded Victorian homes" (McClintock, 1995, p. 219). Apparently, this stream must have surged over Doyle to the extent of convincing him of the superiority of his fellow English people.

\section{The Two Transportations in "The Speckled Band": An Ineffective Persuasion}

At this point, we can clearly see the duality of Doyle's process of transporting his readers into the bosom of the British Empire. David Stewart notices that the major source of readers' thrill in reading detective fiction is how the crime, representing disruption and disorder, disquiets them (Stewart, 1997, p. 677). In other words, there are two narratives in detective fiction: the narrative of the criminal and the narrative of the detective, which generate "the twin narrative drives" characteristic of detective fiction (Chen, 2004, p. 186). By Green and Brook's model, two narratives mean two transportations; Doyle has to transport his readers twice to persuade his readers of British imperialism. In "The Speckled Band”, readers see Dr. Roylott threaten Sherlock Holmes:

"I will go when I have had my say. Don't dare to meddle with my affairs. I know that Miss Stoner has been here-I traced her! I am a dangerous man to fall foul of! See here". He stepped swiftly forward, seized the poker, and bent it into a curve with his huge brown hands. (p. 221)

At this moment, readers are transported into a narrative scenario where Britain's social order (Sherlock Holmes) is under alien threat (Dr. Roylott); as Dr. Roylott bends the poker "into a curve with his huge brown hands", the strength of the alien threat simply manifests itself. This is their first transportation. Later at the end of the story, they read,

Beside this table, on the wooden chair, sat Dr. Grimesby Roylott, clad in a long grey dressing-gown, his bare ankles protruding beneath, and his feet thrust into red heelless Turkish slippers. Across his lap lay the short stock with the long lash which we had noticed during the day. His chin was cocked upwards, and his eyes were fixed in a dreadful rigid stare at the corner of the ceiling. (p. 227)

The quoted passage depicts Dr. Roylott's death; with his death the alien threat, of which he is such a 
paradigm, is neutralized. Right away, readers are under the impression that the British law prevails at last, and that the British colonies, undeveloped and menacingly evil, are once again subjugated and placed under the governance of the British Empire. This is their second transportation; this narrative transports them into the bosom of the British Empire because it persuades them to have faith in the solidity of the British imperialism.

It's plain to see that the two narratives are causally interrelated; on the other hand, my emphasis here is that the twin narrative drives work in opposite directions (Chen, 2004, p. 186) and therefore the two narratives have to be complementary. One narrative exposes the British Empire's temporary lack of order and stability caused by the alien invasion, while the other is the no-more-lack narrative; namely, this lack is instantly overcome owing to the detective's intervention. The complementarity of the two narratives or transportations is the key facilitator of Doyle's persuasion; that is, Doyle can persuade his readers that British imperialism is worth embracing only after he shows them that the security of the empire is compromised. On the other hand, once this complementarity is undermined, readers will not successfully be transported into the bosom of the British Empire. In detective fiction, the detective as well as his reasoning is synonymous with the state's justice system, as the author have repeatedly emphasized. If the detective, by any chance, has defied the law or moral code, the two narratives will no longer be a complementary pair, and the persuasive effect Doyle aims to create will consequently be offset. Throughout the Sherlock Holmes stories, Sherlock Holmes has constantly crossed the legal and moral boundaries. Behind his image of justice is how he has transgressively put his individualism over social order. As a consequence, the line between Sherlock Holmes and the criminals is getting blurred (Chen, 2004, pp. 191-3). In “The Speckled Band”, Sherlock Holmes trespasses on Dr. Roylott's manor house as if there were no such an offense as breaking and entry:

There was little difficulty in entering the grounds, for unrepaired breaches Gaped in the old park wall. Making our way among the trees, we [Sherlock Holmes and Dr. Watson] reached the lawn, crossed it, and were about to enter through the window...I [Dr. Watson] confessed that I felt easier in my mind when, after following Holmes' example and slipping off my shoes, I found myself inside the bedroom. (p. 226, italics mine)

And after Sherlock Holmes kills Dr. Roylott with his own adder, he says, "I cannot say that it is likely to weigh very heavily upon my conscience" (p. 229). Having taken justice into his own hands, Sherlock Holmes shows extreme disrespect for the British law or police, which had already been a longstanding institution in Victorian London. In other words, readers, after reading “The Speckled Band”, simply don't get transported into the bosom of the British Empire; instead, they get transported into a position where they get to impugn Sherlock Holmes' incarnation of the British law and justice. To be more specific, the second transportation is supposed to inform readers that the British Empire no longer has a lack of law and order; ironically, it "tacitly acknowledges its [very] lack" of it. Thus, readers get to have a rude awakening that "British imperial power...never achieves sure mastery of its domains and subjects" (Keep \& Randall, 1999, p. 218, italics mine). That is, while Doyle is celebrating "the power and strength of the imperial body" in the story, he is also suggesting its vulnerability (Siddiqi, 2006, p. 241). In a way, it also indicates that the two narratives or transportations in "The Speckled Band", which should have been respectively functional in serving the purpose of persuading readers, are in fact disrupted and merged into each other, which renders Doyle's effort to persuade his readers utterly futile. That is, the narrative persuasion of "The Speckled Band" is arrantly ineffective. 


\section{Conclusion}

Generally speaking, "Doyle's readers...want to see themselves as living in a land of law and order" (Otis, 1999, pp. 116-7). That's why Doyle characterizes Sherlock Holmes as "the champion of the law" (Doyle, 1996b, p. 446). "The air of London is the sweeter for my [Sherlock Holmes'] presence" (p. 443, italics mine). Therefore, Sherlock Holmes stories, including "The Speckled Band", have a Manichean structure: the detective (representing law and order) versus the villains (embodying unlawfulness and disorder). Take Doyle's "The Speckled Band" for instance. When Sherlock Holmes infers the truth and kills Dr. Roylott, Doyle conveys to his readers a compelling message that law and reason has expelled the alien invasion and continues to rule the center of the British Empire. If we apply Green and Brock's transportation-imagery model, which emphasizes narrative imagery "as the engine of enduring narrative impact" (Brock, Green, \& Strange, 2002, p. 352) to this story, it would appear that Doyle has woven two narratives into it, namely, the narrative of Sherlock Homes and the narrative of Dr. Roylott. Obviously, Doyle seeks to implicate his readers in two transportations: he wants to persuade his readers to see the threat posed by the alien culture, and then he wants to persuade them that the British Empire's law will crush any alien transgression. However, if we further rethink Doyle's binary-transportation mechanism, we'll see that it's actually falling apart. The main reason is that Sherlock Holmes occasionally becomes lawlessness incarnate in "The Speckled Band”. By Green and Brock's model, Doyle is literally persuading his readers of how British law has lost its grip on the British Empire. In conclusion, it is highly questionable whether Doyle can transport his readers into the bosom of the British Empire or persuade his readers of British imperialism in "The Speckled Band".

\section{References}

Adams, J. K. (1985). Pragmatics and fiction. Amsterdam: John Benjamin.

Allbritton, D. W., \& Gerrig, R. J. (1991). Participatory responses in text understanding. Journal of Memory and Language, 30, 603-26.

Batty, N. E. (1987). The art of suspense: Rushdie's 1001 (mid-) nights. Ariel, 18, 49-65.

Bennett, T. (1986). Marxism and popular fiction. In P. Humm, P. Stigant, \& P. Widdowson (Eds.), Popular fictions: Essays in literature and history (pp. 237-65). London: Methuen.

Black, J. (1999). (De)feats of detection: The spurious key text from Poe to Eco. In P. Merivale, \& S. E. Sweetney (Eds.), Detecting texts: The metaphysical detective story from poe to postmodernism (pp. 75-98). Philadelphia: University of Pennsylvania Press.

Brand, D. (1990). From the Flâneur to the detective: Interpreting the city of Poe. In Popular Fiction: Technology, Ideology, Production, Reading (pp. 220-37). London: Routledge.

Bruner, J. (1986). Actual minds, possible worlds. Cambridge, MA: Harvard University Press.

Cawelti, J. G. (1976). Adventure, mystery, and romance: Formula stories as art and popular culture. Chicago: University of Chicago Press.

Chen, Y. I. (2004). Returning to order or indulging in gaps: The Twin narrative drives in the Sherlock Holmes Detective Stories. Journal of English and American Literature, 7, 163-207.

Cohen, M. (2000). Murder most fair: The appeal of mystery fiction. Cranbury, New Jersey: Associated University Press.

Dadds, M. R., Bovbjerg, D. H., Redd., W. H., \& Cutmore, T. R. H. (1997). Imagery in human classical conditioning. Psychological Bulletin, 127, 89-103.

Doyle, A. C. (1996a). The Speckled Band. In The Adventures of Sherlock Holmes (pp. 214-39). Hertfordshire: Wordsworth Editions Limited.

Doyle, A. C. (1996b). The final problem. In The Adventures of Sherlock Holmes (pp. 435-46). Hertfordshire: Wordsworth Editions Limited.

Erb, P. C. (2007). Murder, manners, mystery. London: SCM Press. 
Frank, L. (2003). Victorian detective fiction and the nature of evidence: The scientific investigations of Poe, Dickens, and Doyle. New York: Palgrave Macmillan.

Gerrig, R. J. (1993). Experiencing narrative worlds: On the psychological activities of reading. New Haven: Yale University Press.

Gerrig, R. J., \& Prentice, A. D. (1996). Notes on audience response. In D. Bordwell, \& N. Carroll (Eds.), Post-Theory: Reconstructing Film Studies (pp. 389-97). Madison, Wisconscin: The University of Wisconscin Press.

Gibson, W. (1980). Authors, speakers, readers, and mock readers. In J. P. Thompson (Ed.), Reader-Response Criticism (pp. 1-6). Baltimore: John Hopkins University.

Green, M. C., \& Brock, T. C. (2002). Transportation-imagery model of narrative persuasion. In M. C. Green, J. J. Strange, \& T. C. Brock (Eds.). Narrative Impact: Social and Cognitive Foundations (pp. 315-43). Mahwah, New Jersey: Lawrence Erlbaum Associates.

Green, M. C., Brock, T. C., \& Strange, J. J. (2002). Insights and research implications: Epilogue to narrative impact. In M. C. Green, J. J. Strange, \& T. C. Brock (Eds.), Narrative Impact: Social and Cognitive Foundations (pp. 315-43). Mahwah, New Jersey: Lawrence Erlbaum Associates.

Groves, D. (2003). Better Holmes and Gardens: Sense of place in the Sherlock Holmes stories. Journal of Popular Culture, 36(3), 466-72.

Harris, S. C. (2003). Pathological possibilities: Contagion and empire in Doyle's Sherlock Holmes stories. Victorian Literature and Culture, 31, 447-66.

Jacobs, R. N. (2002). The narrative integration of personal and collective identity in social movements. In M. C. Green, J. J. Strange, \& T. C. Brock (Eds.), Narrative Impact: Social and Cognitive Foundations (pp. 205-29). Mahwah, New Jersey: Lawrence Erlbaum Associates.

James, P. D. (1989). The art of the detective novel. The Welsh Review, 2(1), 4-9.

Johnson, M., \& Foreword, K. (2002). Narrative impact: Social and cognitive foundations. In M. C. Green, J. J. Strange, \& T. C. Brock (Eds.). Mahwah, New Jersey: Lawrence Erlbaum Associates.

Keep, C., \& Randall, D. (1999). Addiction, empire, and narrative in Arthur Conan Doyle's "The Sign of the Four". Novel: A Forum on Fiction, 32(2), 207-21.

Labov, W. (1972). Language in the inner city: Studies in the black English vernacular. Philadelphia: University of Pennsylvania Press.

McBratney, J. (2005). Racial and criminal types: Indian ethnography and Sir Arthur Conan Doyle's "The Sign of Four". Victorian Literature and Culture, 33, 149-67.

McClintock, A. (1995). Imperial leather: Race, gender, and sexuality in the colonial contest. New York: Routledge.

Nell, V. (1988). Lost in a book: The psychology of reading for pleasure. New Haven: Yale University Press.

Oatley, K. (2002). Emotions and the story worlds of fiction. In M. C. Green, J. J. Strange, \& T. C. Brock (Eds.), Narrative Impact: Social and Cognitive Foundations (pp. 39-71). Mahwah, New Jersey: Lawrence Erlbaum Associates.

Otis, L. (1999). Membranes: Metaphors of invasion in nineteenth-century literature, science, and politics. Baltimore: John Hopkins University.

Pederson-Krag, G. (1983). Detective stories and the primal scene. In G. W. Most, \& W. W. Stowe (Eds.), The Poetics of Murder: Detective Fiction and Literary Theory (pp. 13-20). London: Harcourt Brace Jovanovich Publishers.

Polichak, J. W., \& Gerrig, R. J. (2002). “Get Up and Win!”: Participatory responses to narrative. In M. C. Green, J. J. Strange, \& T. C. Brock (Eds.), Narrative Impact: Social and Cognitive Foundations (pp. 71-97). Mahwah, New Jersey: Lawrence Erlbaum Associates.

Pratt, M. L. (1977). Toward a speech act theory of literary discourse. Bloomington: Indiana University Press.

Raheja, L. (2006). Anxieties of empire in Doyle's Tales of Sherlock Holmes. Nature, Society, and Thought, 19(4), 417-26.

Robertson, D. J. (2012). The curious case of Sherlock Holmes and Perceptual Load. Psychologist, 25(6), 472-4.

Rothfield, L. (1992). Vital signs: Medical realism in nineteenth-century fiction. Princeton: Princeton University Press.

Schank, R. C., \& Abelson, R. P. (1995). Knowledge and memory: The real story. In R. S. Wyer (Ed.), Advances in Social Cognition (pp. 1-86). Hillsdale, New Jersey: Lawrence Erlbaum Associates.

Schank, R. C., \& Berman, T. R. (2002). The pervasive role of stories in knowledge and action. In M. C. Green, J. J. Strange, \& T. C. Brock (Eds.), Narrative Impact: Social and Cognitive Foundations (pp. 287-315). Mahwah, New Jersey: Lawrence Erlbaum Associates.

Searle, J. R. (1975). The logical status of fictional discourse. New Literary History, 6, 325. 
Siddiqi, Y. (2006). The Cesspool of Empire: Sherlock Holmes and the return of the repressed. Victorian Literature and Culture, $34,233-47$.

Simmons, D. (2007). The narcissism of Empire: Loss, rage, and revenge in Thomas De Quincey, Robert Louis Stevenson, Arthur Conan Doyle, Rudyard Kipling and Isak Dinesen. Brighton: Sussesx Academic Press.

Slater, M. D. (2002). Entertainment education and the persuasive impact of narratives. In M. C. Green, J. J. Strange, \& T. C. Brock (Eds.), Narrative Impact: Social and Cognitive Foundations (pp. 157-83). Mahwah, New Jersey: Lawrence Erlbaum Associates.

Stewart, D. (1997). Cultural work, city crime, reading, pleasure. American Literary History, 9(4), 676-701.

Strange, J. J. (2002). How fictional tales wag real-world beliefs. In M. C. Green, J. J. Strange, \& T. C. Brock (Eds.), Narrative Impact: Social and Cognitive Foundations (pp. 263-87). Mahwah, New Jersey: Lawrence Erlbaum Associates.

Strange, J. J., \& Leung, C. C. (1999). How anecdotal accounts in news and in fiction can influence judgments of a social problem's urgency, causes, and cures. Personality and Social Psychology Bulletin, 25(4), 436-49.

Thompson, J. (1993). Fiction, crime, and empire: Clues to Modernity and postmodernism. Chicago: University of Illinois Press.

Todorov, T. (1977). The typology of detective fiction. In The Poetics of Prose (pp. 42-52). Oxford: Basil Blackwell.

Wolfreys, J. (1996). Introduction. In The Adventures of Sherlock Holmes (pp. V-XII). Hertfordshire: Wordsworth Editions Limited.

Zizek, S. (1991). Looking Awry: An introducction to Jacques Lacan through popular culture. Cambridge: MIT Press. 